\title{
PERUBAHAN KELEMBABAN RELATIF (RH) PADA RUANGAN PERTENUNAN AJL TERHADAP EFISIENSI DAN GRADE KAIN YANG DIHASILKAN
}

Oleh :

Sajinu A P., Neoyi dan Asril Senoaji S.

Staf Pengajar Sekolah Tinggi Teknologi Tekstil

\begin{abstract}
Relative Humidity $(\mathrm{RH})$ is the amount of water vapor in a space or a room that make the room become humid and wet in the same temperature. The humidity presentation is amount of content of water vapor in a room. The value of humidity is an important factor because it can influence the machine efficiency and fabric quality

A hot and dry condition will make the strength of processed cotton yarn decrease, which in this case influences the amount of broken yarn and machine efficiency, also the probability of the decreasing of fabric quality processed.

In this observation, writer observed the value of humidity in three variables of humidity value $(R H)$, that are $61 \%, 63 \%$, and $65 \%$ of AJL 'Tsudakoma ZA-205' machine efficiency and focused in Carded yarn $\mathrm{Ne}_{1} 40$.

$R H$ value of $63 \%$ shows the efficiency value of $88,69 \%$ and this value is the biggest efficiency among all $\mathrm{RH}$ that was observed. $\mathrm{RH}$ of $63 \%$, also shows a good machine work and good quality of fabric that percentage of grade A1 and A2 is $90,8 \%$.
\end{abstract}

\section{INTISARI}

Kelembaban Relatif atau Relative Humidity $(\mathrm{RH})$ yaitu banyaknya uap air yang ada di dalam ruangan yang membuat ruangan menjadi lembab dan basah pada suhu yang sama. Persentase kelembaban adalah jumlah kandungan uap air di dalam ruangan. Besarnya nilai kelembaban merupakan faktor penting yang harus diperhatikan karena dapat mempengaruhi efisiensi mesin dan kualitas kain

Keadaan yang panas dan kering akan membuat kekuatan benang kapas yang diproses menurun sehingga dapat mempengaruhi jumlah putus benang dan efisiensi mesin yang kemudian diikuti oleh kemungkinan turunnya grade kain yang dihasilkan.

Pada pengamatan ini penulis mengamati pada nilai temperatur $29{ }^{\circ} \mathrm{C}$ dalam tiga variable nilai kelembaban $(\mathrm{RH})$ yaitu: $61 \%$, 63\% dan $65 \%$ terhadap efisiensi mesin AJL merek Tsudakoma ZA-205 dan terfokus pada benang Carded $\mathrm{Ne}_{1}$ 40. 
Pada nilai $\mathrm{Rh} 63 \%$ menunjukan nilai efisiensi $88,69 \%$ dan pada nilai ini pula dicapai tingkat efisiensi terbesar diantara nilai lainnya yang diamati. Pada nilai kelembaban $63 \%$ juga dicapai tingkat kelancaran mesin dan grade kain yang baik, dengan persentase grade A1 dan A2 sebesar 90,8\%.

\section{Pendahuluan}

Udara panas di dalam ruangan pertenunan yang dikarenakan oleh Air Conditioner (AC) mati merupakan salah satu faktor terjadinya banyak putus benang. Udara panas ini juga merubah nilai suhu dan kelembaban standar di dalam ruangan tersebut. Nilai standar yang digunakan di dalam perusahaan untuk ruangan pertenunan adalah suhu $29^{\circ} \mathrm{C}$ dan $\mathrm{RH} 60 \%$. Akibat udara yang panas, suhu dan kelembaban ruangan menjadi $32^{\circ} \mathrm{C}$ dan $58 \%$. Perubahan suhu dan kelembaban di ruangan ini menjadi sebuah permasalahan karena menyebabkan efisiensi mesin menjadi turun di bawah $82 \%$.

Pengaturan kelembaban di ruangan adalah salah satu faktor yang mempengaruhi efisiensi mesin AJL. Kelembaban lebih dikenal dengan nama singkatan $\mathrm{RH}$ yaitu Relative Humidity. Pengaturan kelembaban yang tepat di dalam ruangan pertenunan dapat mempengaruhi jumlah putus benang lusi dan putus benang pakan pada saat proses berlangsung. Oleh karena itu, pengaturan kelembaban di dalam ruangan dapat menciptakan kelancaran pada proses pertenunan yang baik dan menjaga efisiensi mesin, tetapi sebaliknya apabila pengaturan kelembaban di dalam ruangan tidak sesuai, maka dapat membuat kinerja mesin menjadi tidak lancar karena mesin sering berhenti akibat terjadinya putus benang yang lebih banyak pada saat proses produksi berlangsung, hal ini berpotensi mengakibatkan penurunan efisiensi mesin. Disamping itu, semakin sering terjadi putus benang pada saat proses produksi berlangsung akan berdampak pada kemungkinan terjadinya cacat kain yang lebih besar sehingga dapat menurunkan grade dari kain yang dihasilkan.

Keberhasilan dari proses pertenunan ditentukan oleh banyak faktor yaitu: kondisi mesin, bahan baku yang dipergunakan, kecepatan (Rpm), jenis konstruksi kain yang sedang diproses, pelayanan operator terhadap mesin apabila terjadi putus benang, suhu serta kelembaban di dalam ruangan produksi dan lain-lain.

Penulis ingin melakukan pembahasan tentang seberapa besar pengaruh perubahan kelembaban di dalam ruangan proses pertenunan terhadap kelancaran mesin untuk peningkatan efisiensi mesin.

Dari uraian diatas maka kemudian timbul pertanyaan sebagai berikut:

Apakah peningkatan nilai kelembaban ruangan akan mempengaruhi efisiensi mesin?

Apakah perubahan kelembaban ruangan akan mempengaruhi grade kain?

Pengaturan kelembaban di dalam ruangan proses pertenunan merupakan salah satu faktor penting dalam rangka memperoleh efisiensi mesin yang tinggi dan kualitas kain yang terbaik, dengan berubahnya nilai kelembaban ini akan 
mempengaruhi jumlah putus benang pada saat proses pertenunan berlangsung yang akan berpengaruh pada nilai efisiensi mesin. Dengan demikian kestabilan kelembaban ruangan perlu dipertahankan pada kondisi yang optimal dan tepat guna untuk menghasilkan efisiensi yang tinggi serta kualitas kain yang tetap baik.

Ruangan dengan kelembaban rendah akan mengakibatkan efisiensi mesin menjadi rendah dikarenakan mesin sering berhenti yang disebabkan banyaknya putus benang pada saat proses pertenunan berlangsung. Pada kondisi ruangan yang lebih lembab, benang-benang kapas akan lebih banyak menyerap air sehingga kekuatan benangnya akan lebih tinggi bila dibandingkan dengan benang kapas yang lebih kering. Karena kekuatan benang basah lebih tinggi dari pada benang kering, maka pada saat proses pertenunan kemungkinan jumlah benang putus akan berkurang sehingga kemungkinan intensitas mesin berhenti pun akan berkurang pula, dengan kata lain efisiensi mesin akan lebih terjaga.

Penelitian ini dimaksudkan untuk mengetahui seberapa besar pengaruh kelembaban ruangan terhadap efisiensi pada saat proses pertenunan dan kualitas kain yang dihasilkan. Sedang tujuannya adalah untuk mendapatkan nilai kelembaban ruang produksi yang optimal.

\section{METODE DAN BAHAN}

Penelitian ini dilakukan secara eksperimental di Ruang Pertenunan Seksi 1 dari PT. X pada kondisi suhu ruangan $29^{\circ} \mathrm{C}$ dengan variasi perubahan kelembaban $(\mathrm{RH}): 61 \%, 63 \%$ dan $65 \%$. Dari perubahan $\mathrm{RH}$ ruangan tersebut diharapkan dapat diketahui perubahan efisiensi yang terjadi dan perubahan grade dari kain yang dihasilkannya.

Adapun spesifikasi mesin dan kain yang dijadikan sebagai pengamatan di Ruang Proses Pertenunan Seksi I adalah sebagai berikut:

$\begin{array}{ll}\text { Nama mesin } & : \text { Air Jet Loom } \\ \text { Merek } & : \text { Tsudakoma ZA-205 } \\ \text { Rpm rata-rata } & : 650 \mathrm{rpm} \\ \text { Tahun pembuatan } & : 1989 \\ \text { Buatan } & : \text { Jepang } \\ \text { Lebar mesin } & : 150 \mathrm{~cm} \\ \text { Jenis konstruksi } & : \text { Polos } 104 \\ \text { Anyaman } & : \text { Carded } \mathrm{Ne}_{1} 40 \\ \text { No benang lusi } & : \text { Carded } \mathrm{Ne}_{1} 40 \\ \text { No benang pakan } & : 120 \mathrm{hl} / " \\ \text { Tetal Lusi } & : 60 \mathrm{hl} / " \\ \text { Tetal Pakan } & : 47 \text { inch } \\ \text { Lebar Kain } & : 139 \text { Yard } \\ \text { Panjang Kain } & \end{array}$




\section{DATA HASIL PENGAMATAN}

1. Pengamatan terhadap nilai efisiensi dengan kelembaban dan suhu yang ada pada ruangan selama 30 hari.

Tabel 1. Efisiensi produksi terhadap perubahan kelembaban ruangan $(\mathrm{RH})$

\begin{tabular}{|r|r|r|r|}
\hline RH (\%) & \multicolumn{1}{|c|}{$61 \%$} & \multicolumn{1}{c|}{$63 \%$} & \multicolumn{1}{c|}{$65 \%$} \\
\hline Efisiensi & 86.70 & 88.69 & 88.51 \\
\hline
\end{tabular}

2. Pengamatan terhadap grade kain pada setiap perubahan $\mathrm{RH}$ dengan konstruksi diatas.

Tabel 2. Persentase rata-rata grade kain terhadap perubahan kelembaban ruangan $(\mathrm{RH})$

\begin{tabular}{|c|r|r|r|r|}
\hline Kelembaban (RH) & $\begin{array}{c}\text { Grade A1 dan A2 } \\
\text { (\%) }\end{array}$ & $\begin{array}{c}\text { Grade A3 } \\
(\%)\end{array}$ & $\begin{array}{c}\text { Grade B } \\
\text { (\%) }\end{array}$ & \multicolumn{1}{c|}{$\begin{array}{c}\text { Grade C } \\
(\%)\end{array}$} \\
\hline $61 \%$ & 86.2 & 3.45 & 5.18 & 5.18 \\
\hline $63 \%$ & 90.8 & 8.05 & 0.00 & 1.15 \\
\hline $65 \%$ & 84.8 & 9.66 & 1.38 & 4.14 \\
\hline
\end{tabular}

\section{PEMBAHASAN}

Ada beberapa hal yang menjadi bahan diskusi penulis dari hasil pengamatan yang dilakukan, hal-hal tersebut adalah sebagai berikut:

1. Kelembaban relatif atau Relative Humidity $(\mathrm{RH})$ di dalam ruangan adalah faktor penting yang harus diperhatikan dalam melakukan proses pertenunan karena kelembaban di dalam ruangan proses dapat mempengaruhi efisiensi. Efisiensi produksi dipengaruhi oleh jam jalan mesin dan jam jalan mesin dipengaruhi oleh lamanya berhenti mesin karena adanya gangguan. Gangguan yang terjadi pada proses pertenunan yang menyebabkan mesin berhenti adalah adanya benang putus. Pada kelembaban yang rendah, benang yang diproses cenderung kering. Benang yang kering kekuatannya lebih rendah dari pada benang basah dan cenderung lebih banyak menimbulkan elektro statis sehingga masing-masing benang menjadi mudah lengket. Dengan turunnya kekuatan benang dan timbulnya elektro statis akan menyebabkan benang cepat putus. Benang yang sering putus akan menyebabkan mesin sering berhenti yang berarti akan menurunkan efisiensi.

Kekuatan benang yang tinggi akan mengurangi putus benang pada saat proses pertenunan. Dengan berkurangnya putus benang berarti berkurang pula stop mesin karena putus benang, atau dengan kata lain 
mesin semakin jarang berhenti. Mesin yang jarang berhenti berarti efsiensinya tetap terjaga.

Hal ini dapat dilihat pada grafik dibawah ini yang menunjukan hubungan antara kelembaban ruangan proses dengan efisiensi mesin yang dihasilkan

Gambar 1 Grafik hubungan antara RH dengan Efisiensi

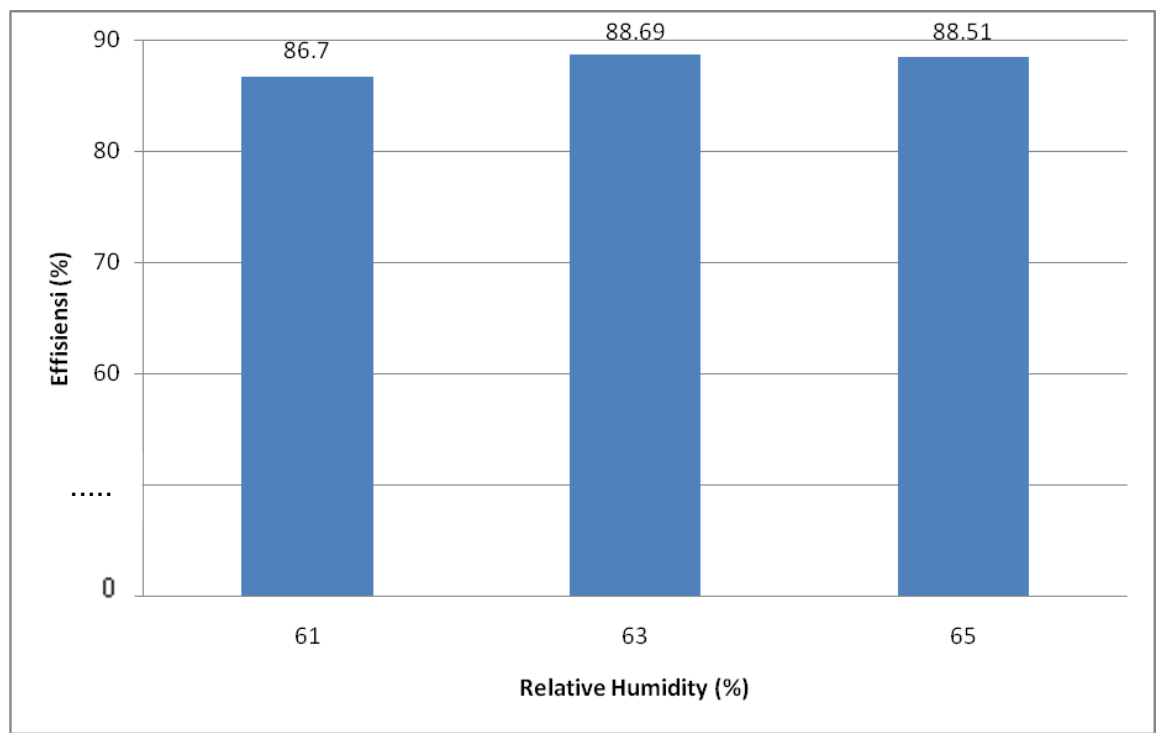

Dari grafik diatas dapat dilihat bahwa efisiensi mesin semakin naik seiring dengan naiknya kelembaban, namun pada kelembaban 65\% efisiensi mesin justru malah turun hal ini berbeda dengan hipotesa awal yaitu semakin tinggi nilai kelembaban akan semakin tinggi pula nilai efisiensi mesin yang dihasilkan. Pada keadaan ruangan yang terlalu lembab melebihi 63\% membuat benang menjadi lebih basah sehingga benang lebih sulit untuk diluncurkan oleh angin pada main nozzle karena berat benang menjadi lebih tinggi dari sebelumnya sehingga mesin dapat berhenti.

2. Grade kain yang terjadi dikelompokkan menjadi Grade A1 dan A2, Grade A3, Grade B dan Grade C. Grade kain yang terbaik adalah Grade A1 dan A2. Apabila diperhatikan, persentase grade kain A1 dan A2 tidak signifikan terpengaruhi oleh kelembaban seperti terlihat pada grafik ini. 


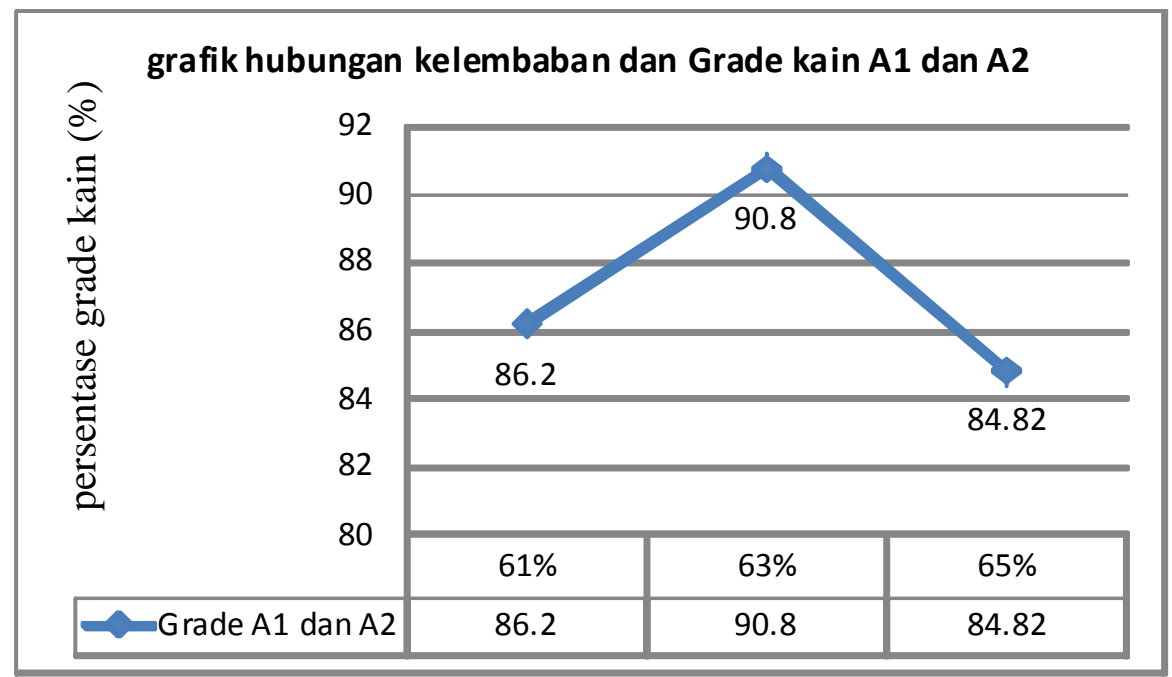

Gambar 2 Grafik hubungan kelembaban dan Grade kain A1 dan A2

Dari grafik diatas dapat terlihat bahwa persentase Grade kain A1 dan A2 tidak signifikan terpengaruhi oleh kelembaban. Naiknya kelembaban tidak langsung menaikkan grade kain. Ada faktor-faktor lain yang mungkin lebih dominan mempengaruhi dari pada faktor kelembaban. Disini penulis tidak mengamati factor-faktor lain tersebut. Grade kain tertinggi terjadi pada waktu kelembaban di dalam ruangan adalah $63 \%$.

3. Nilai Kelembaban yyang optimum terjadi pada kelembaban $63 \%$. Pada kelembaban ini efisiensi produksi mencapai nilai tertinggi yaitu $88,69 \%$ dan grade kain A1 dan A2 yang dihasilkan juga yang terbaik yaitu 90,8 \%

\section{KESIMPULAN}

1. Kelembaban Relatif $(\mathrm{RH})$ di dalam ruangan pertenunan mempengaruhi efisiensi proses pertenunan.

2. Makin tinggi kelembaban relatif $(\mathrm{RH})$ sampai titik tertentu akan menjaga efisiensi tetap tinggi.

3. Kelembaban relatif $(\mathrm{RH})$ di dalam ruangan pertenunan tidak siginifikan mempengaruhi grade kain yang dihasilkan.

4. Kelembaban relatif $(\mathrm{RH})$ di dalam ruangan pertenunan yang optimum pada penelitian ini ada pada $63 \%$. 


\section{DAFTAR PUSTAKA}

1. Adanur, Sabit. Ahli bahasa Giarto. Pengetahuan Teknologi Pertenunan. Department of Textile Engineering Auburn University Alabama. USA. 2009

2. Jumaeri. Textile Design. Institut Teknologi Tekstil. Bandung

3. Soeprijono. Serat-Serat Tekstil. Institut Teknologi Tekstil. Bandung.

4. Suseno Utomo, Metoda Statistika Untuk Industri Tekstil, Institut Teknologi Tekstil, Bandung, 1973.

5. Wibowo Moerdoko. Evaluasi Tekstil Bagian Fisika. Institut Teknologi Tekstil. Bandung. 1973

6. $\quad$ Panduan Dasar Setting Tsudakoma Air Jet Loom. PT. Primatexco Indonesia. Batang . 2010

7. $\quad$ Praktek Pengenalan Industry Tekstil Indonesia dan Pendukungnya. teddypram.blogspot.com. 2011

$8 . \quad$ Teknik Pendinginan. web.ipb.ac.id/..bab9.php 